\title{
ANALISIS FAKTOR-FAKTOR YANG MEMPENGARUHI PENGUNGKAPAN CSR DAN DAMPAKNYA TERHADAPNILAI PERUSAHAAN
}

\author{
Muhammad Sulhan \\ Fakultas Ekonomi Universitas Islam Negeri Maulana Malik Ibrahim Malang \\ Jl. Gajayana 50 Malang \\ Email: sulhan100@gmail.com
}

\begin{abstract}
This research aims to analyze factors that affect the company's CSR disclosure and to see the impact of CSR on firm value. The population in this study are all companies listed on the Indonesia Stock Exchange (IDX) and samples are15 companies manufacturing. Analysis of the data used to test the first hypothesis is linear multiple regression analysis is to look at the effect of profitability, leverage, institutional ownership, size, and slack resources on the disclosure of CSR, while to test the hypothesis that both are seeing the effect of CSR on firm value, then used a simple linear regression. The results of this study indicate that the variable profitability, size, and slack resources have a significant impact on CSR. As for the variable leverage and institutional ownership has no significant effect on CSR. The last, variable CSR has a significant influenceon the firm value.
\end{abstract}

Keyword: determinant of CSR disclosure, firm value

Dewasa ini perusahaan tidak hanya dihadapkan pada tanggung jawab dalam perolehan keuntungan semata, tetapi juga harus memperhatikan tanggung jawab sosial dan lingkungannya. Jika masyarakat menganggap perusahaan tidak memperhatikan aspek sosial dan lingkungannya serta tidak merasakan kontribusi secara langsung bahkan merasakan dampak negatif dari beroperasinya sebuah perusahaan maka kondisi itu akan menimbulkan resistensi masyarakat. Oleh karena itu dalam menjaga eksistensinya, perusahaan tidak dapat dipisahkan dengan masyarakat sebagai lingkungan eksternalnya. Ada hubungan resiprokal (timbal balik) antara perusahaan dengan masyarakat.

Orientasi perusahaan seringkali hanyalah untuk meningkatkan kesejahteraan bagi para pemilik (shareholder) dan kreditur. Keberpihakan perusahaan yang hanya kepada pemilik modal mengakibatkan perusahaan melakukan eksploitasi sumbersumber alam dan masyarakat (sosial) secara tidak terkendali sehingga dalam beberapa kasus menimbulkan konflik di tengah-tengah lingkungan masyarakat atau di tubuh perusahaan. Dasar pemikiran ini diadopsi dari Friedman (1962) bahwa satu-satunya tanggung jawab perusahaan hanyalah kepada pemegang saham (single bottom line), sedangkan tanggung jawab sosial perusahaan kepada masyarakat adalah menghasilkan kegiatan ekonomi sehingga perusahaan berlomba mengeruk keuntungan untuk memaksimalkan kemakmuran shareholder (pemegang saham) dengan melakukan aktivitas yang tidak etis.

Pandangan ini kemudian ditentang oleh Freeman (1984:46) bahwa stakeholder sebagai setiap kelompok atau individu yang dapat mempengaruhi atau dipengaruhi oleh pencapaian tujuan perusahaan. Freeman dan Elkington (1998) kemudian mengembangkan konsep triple bottom line dengan tujuan menyatukan kaidah ekonomi, sosial dan lingkungan dalam satu pemahaman terintegrasi tentang tanggung jawab sosial dan lingkungan perusahaan. Konsep ini mempunyai makna bahwa perusahaan tidak hanya mencari laba (profit) sebanyak mungkin, tetapi juga harus memberi kontribusi positif kepada masyarakat (people) ikut aktif dalam menjaga kelestarian lingkungan (planet). Konsep ini dikenal dengan P3 (profit, people, planet). Sustainability (keberlanjutan) adalah keseimbangan antara profit-planet-profit, yang dikenal dengan konsep Triple Bottom Line (TBL) yang terigrasi dalam tanggung jawab sosial perusahaan atau Corporate Social Responsibility (CSR).

Membangun nilai bagi perusahaan tidak hanya dicapai lewat peningkatan ekonomi sebagaimana yang berujung untuk peningkatan pemilik (shareholder), 
melainkan harus memperhitungkan stakeholder lain. Pengakuan terhadap adanya berbagai stakeholders diluar pemegang saham yang dapat mempengaruhi efektifitas pencapaian tujuan perusahaan telah mengubah dimensi tanggung jawab sosial dan lingkungan perusahaan dari tanggung jawab ekonomi sematamata dalam bentuk maksimalisasi laba untuk kemakmuran para pemegang saham menjadi tanggung jawab kepada sejumlah stakeholder yang lebih luas. Untuk memperjelas keberadaannya sebagai institusi kuat yang menggunakan sejumlah sumber daya masyarakat, perusahaan harus lebih fokus pada tanggung jawabnya dan mengarahkan perhatian kepada masyarakat pada pertimbangan proses manajemen keputusan strategis (Menon dan Menon, 1997; Burke dan Logsdon, 1996). Hal ini menjamin ketertarikan tujuan jangka panjang perusahaan melalui penciptaan ikatan erat dengan masyarakat.

Pelaksanaan program corporate social responsibility dan mengungkapkannya baik dalam annual report maupun sustainability report sebagai suatu bentuk informasi yang dibutuhkan investor untuk mengambil keputusan terkait kinerja perusahaan yang sesuai dengan nilai-nilai di dalam masyarakat. Pengungkapan tersebut untuk mencerminkan tingkat akuntabilitas, responsibilitas, dan transparansi korporat kepada investor dan stakeholders lainnya (Machmud dan Djakman, 2008). Pengungkapan tersebut bertujuan untuk menjalin hubungan komunikasi yang baik dan efektif antara perusahaan dengan publik dan stakeholders lainnya tentang bagaimana perusahaan telah mengintegrasikan Corporate Social Responsibility (CSR) dalam setiap aspek kegiatan operasinya (Darwin, 2007).

Beberapa penelitian mengenai motivasi perusahaan dalam melakukan pengungkapan informasi lingkungan telah banyak dilakukan dan menunjukkan hasil yang tidak konsisten. Beberapa penelitian seperti Cowen, et al. (1987): Belkaoui dan Karpik (1989): Ahmad, Hassan, dan Mohammad (2003): Brammer dan Pavelin (2006), Purnomosidhi (2005): Barako, Hancock dan Izan (2006): Reverta (2009), serta Ten (2004): menganalisis faktor-faktor seperti ukuran perusahaan, leverage, struktur kepemilikan dianggap berkaitan dengan tingkat pengungkapan lingkungan. Belkaoui dan Karpik (1989): Ahmad, Hassan,dan Mohammad (2003): serta Brammer dan Pavelin (2006) menemukan pengaruh negatif antara variabel leverage dengan pengungkapan sukarela dilakukan oleh. Namun pendapat berbeda dikemukakan oleh Purnomosidhi (2005): Barako, Hancock dan Izan
(2006) yang menyatakan bahwa leverage mempunyai pengaruh positif terhadap pengungkapan sukarela. Studi yang menguji ukuran perusahaan (size) terhadap pengungkapan CSR menunjukkan hasil yang tidak konsisten. Penelitian yang dilakukan oleh Cowen, et al. (1987): Belkaoui dan Karpik (1989): Purnomosidhi (2005): Brammer dan Pavelin (2006): Barako, Hancock dan Izan (2006) serta Reverta (2009) menemukan size berpengaruh positif terhadap pengungkapan sukarela. Namun Ahmad, Hassan, dan Mohammad (2003) menemukan bahwa size tidak berpengaruh terhadap pengungkapan CSR.

Studi yang menguji pengaruh konsentrasi kepemilikan terhadap pengungkapan CSR menunjukkan hasil yang tidak konsisten. Penelitian yang dilakukan Brammer dan Pavelin (2006) menemukan bahwa semakin terkonsentrasi kepemilikan saham perusahaan semakin besar kemungkinan melakukan pengungkapan CSR. Namun pendapat yang berbeda dikemukakan oleh Reverte (2009) yang menyatakan bahwa konsentrasi kepemilikan berpengaruh negatip terhadap pengungkapan CSR.

Sedangkan beberapa hasil penelitian yang menganalisis pengaruh tanggungjawab lingkungan terhadap nilai keuangan perusahaan misalnya dilakukan oleh Guenster, et al. (2005) yang mendokumentasikan ada pengaruh positip pengungkapan sosial dan lingkungan (diproksikan dengan eco-eficiency) terhadap Tobin's q perusahaan. Curcio dan Wolf (1996) hasil studinya menyatakan bahwa kinerja korporat yang bertanggung jawab akan lingkungan berpengaruh terhadap nilai perusahaan. Beberapa uraian di atas menunjukkan belum adanya konsistensi hasil penelitian tentang determinan dan konsekuensi pengungkapan CSR.

Berdasarkan pada uraian diatas, maka tujuan penelitian ini adalah ingin mengkaji faktor-faktor yang mempengaruhi pengungkapan CSR (profitabilitas, leverage, kepemilikan institusi, size, slack resources) dan dampak pengungkapan CSR terhadap nilai perusahaan manufaktur yang terdaftar di Bursa Efek Indonesia dengan rumusan masalah yaitu Pertama, apakah profitabilitas, size, leverage, slack resources, dan kepemilikan institusional mempunyai pengaruh yang signifikan terhadap pengungkapan CSR perusahaan; Kedua, apakah pengungkapan CSR berpengaruh signifikan terhadap nilai perusahaan.

\section{Determinan Pengungkapan CSR}

Determinan pengungkapan CSR merupakan faktor-faktor yang mempengaruhi pengungkapan CSR 
terdiri dari profitabilitas, size (ukuran perusahaan), leverage, slack resources, dan kepemilikan institusional.

\section{Profitabilitas}

Hubungan antara pengungkapan CSR dan profitabilitas perusahaan telah dipostulasikan untuk merefleksikan pandangan bahwa kepekaan sosial membutuhkan gaya managerial yang sama sebagaimana yang diperlukan untuk dapat membuat perusahaan menguntungkan (profitable) Bowman dan Haire (1976) dalam Heckston dan Milne (1996). Pengungkapan CSR merupakan cerminan suatu pendekatan manajemen dalam menghadapi lingkungan yang dinamis dan multidimensional serta kemampuan untuk mempertemukan tekanan sosial dengan reaksi kebutuhan masyarakat. Dengan demikian, ketrampilan manajemen perlu dipertimbangkan untuk survive dalam lingkungan perusahaan masa kini (Cowen, et al., 1987 dalam Heckston dan Milne, 1996).

Heinze (1976) dalam Heckston dan Milne, (1996) menyatakan bahwa profitabilitas merupakan faktor yang memberikan kebebasan dan fleksibilitas kepada manajemen untuk mengungkapkan pertanggungjawaban sosial kepada pemegang saham. Hal ini berarti semakin tinggi tingkat profitabilitas perusahaan maka semakin besar pengungkapan informasi sosial yang dilakukan oleh perusahan.

Heinze (1976) dalam Heckston dan Milne, (1996) menyatakan bahwa profitabilitas merupakan faktor yang memberikan kebebasan dan fleksibilitas kepada manajemen untuk mengungkapkan pertanggungjawaban sosial kepada pemegang saham. Hal ini berarti semakin tinggi tingkat profitabilitas perusahaan maka semakin besar pengungkapan informasi sosial yang dilakukan oleh perusahan. jawab sosial perusahaan. Sedangkan penelitian yang dilakukan Hackston dan Milne (1996) dan Belkaoui dan Karpik (1989) melaporkan bahwa profitabilitas tidak berpengaruh terhadap pengungkapan tanggung jawab sosial perusahaan.

\section{Size (Ukuran Prusahaan)}

Ukuran perusahaan menunjukkan nilai total aktiva yang dimiliki perusahaan yang disajikan dalam laporan keuangan. Para peneliti menggunakan ukuran perusahaan sebagai proksi dari sensitivitas politik perusahaan. Para peneliti sebelumnya menggunakan nilai total asset perusahaan sebagai ukuran perusahaan. Semakin besar nilai total aset perusahaan maka perusahaan yang bersangkutan dapat dikatakan berukuran besar. Demikian pula sebaliknya, semakin kecil nilai aset perusahaan maka dapat dikatakan bahwa perusahaan yang bersangkutan berukuran kecil. Ukuran perusahaan dalam berbagai penelitian terbukti merupakan faktor signifikan dalam menjelaskan perbedaan tingkat pengungkapan informasi (Belkaoui, dan Karpik 1989; Purnomosidhi, 2005; Brammer dan Pavelin, 2006; Reverte, 20009; Rofelawati, 2010). Hal ini disebabkan antara lain adanya kebutuhan untuk memperoleh dana dengan biaya rendah, desakan dari para stakeholder dan analisis investasi untuk memperoleh informasi yang lebih banyak, pemantauan yang dilakukan pemerintah semakin ketat, struktur bisnis yang semakin rumit, dan tuntutan yang semakin besar untuk menyediakan informasi bagi berbagai kelompok pemakai (Purnomosidhi, 2005).

\section{Leverage}

Leverage menunjukkan proporsi atas penggunaan utang untuk membiayai investasi perusahaan. Kondisi perusahaan-perusahaan di Indonesia sangat bergantung pada utang bank untuk mendanai ekspansinya yang cepat karena pendanaan internal tidak memadai dan pasar modal belum berkembang dengan baik (Husnan, 2001). Perusahaan publik di Indonesia sangat bergantung pada kreditur. Freeman (1984) menyatakan bahwa kreditur merupakan salah satu dari the primary stakeholders (penyedia utama sumber daya perusahaan) dan merupakan stakeholders power yang harus dipertimbangkan (Ullman, 1985). Para kreditur mengendalikan akses perusahaan terhadap sumber daya keuangan yang diperlukan bagi kelangsungan operasi perusahaan.

Analisis stakeholder telah digunakan di dalam penelitian sebelumnya menjelaskan keputusan perusahaan mengenai kebijakan keuangan (Cornell dan Shapiro, 1987; Barton, Hill dan Sundaram, 1989). Hasil penelitian menemukan bahwa keputusan struktur modal adalah bagian dari struktur stakeholder perusahaan secara keseluruhan dan kreditur adalah stakeholder penting yang memiliki pengaruh harus dikelola oleh perusahaan. Dengan demikian, dapat disimpulkan bahwa semakin bergantung sebuah perusahaan pada pendanaan utang untuk mendanai proyeknya, semakin besar tingkat respon yang diberikan manajemen terhadap pengharapan kreditur atas peran perusahaan dalam melaksanakan kegiatan tanggung jawab sosial. 


\section{Slack Resources}

Sumber daya diskresioner adalah kelonggaran organsisasi (organizational slack). Organizational slack didefinisikan sebagi sumber daya yang tidak digunakan atau belum dikomitmenkan untuk tujuan apapun, atau sebagai ketersediaan sumber daya berlebih melampaui tingkat sumber daya minimal yang diperlukan untuk mempertahankan keutuhan dari organisasi (Cyert dan March, 1963) atau kelebihan sumber daya melampaui tingkat sumber daya yang diperlukan untuk menghasilkan tingkat output tertentu (Nohria dan Gulati, 1996). Para peneliti telah mengonseptualisasikan berbagai jenis kelonggaran sumber daya (seperti kelebihan bahan baku, tenaga kerja, kelebihan work in process, atau sisa kapasitas mesin), tetapi bentuk sumber daya yang paling diskresioner adalah kelebihan dana (Sharfman, et al., 1988).

Slack resources yang dimiliki perusahaan dapat digunakan untuk memenuhi kewajiban kepada pemegang saham dan akan lebih kecil kemungkinannya untuk mendapatkan tekanan dari stakeholder keuangan lain seperti kreditur. Dengan demikian, implementasi CSR diharapkan dapat menjadi peredam keinginan stakeholder perusahaan.

\section{Kepemilikan Institusional}

Kepemilikan institusional adalah kepemilikan saham oleh pihak-pihak yang berbentuk institusi, seperti bank, perusahaan asuransi, perusahaan investasi, dana pensiun dan institusi lainnya (Wahidahwati, 2001). Institusi sebagai pemegang saham mayoritas biasanya dapat mengurangi mayoritas saham karena memiliki sumber daya yang lebih besar dibandingkan dengan pemegang saham lainnya. Dengan penguasaan saham mayoritas, pihak institusi dapat melakukan monitoring terhadap kebijakan manajemen secara besar dibandingkan dengan pemegang saham minoritas. Konsentrasi kepemilikan dapat menjadi mekanisme internal pendisiplinan manajemen, sebagai salah satu mekanisme yang dapat digunakan untuk meningkatkan efektivitas monitoring karena dengan kepemilikan yang besar menyebabkan pemegang saham memiliki akses informasi yang cukup signifikan untuk mengimbangi keuntungan informasi yang dimiliki manajemen (Hubert dan Langge, 2002), jika hal ini dapat diwujudkan tindakan moral hazard manajemen berupa menyembunyikan informasi dapat dikurangi.

Haniffa dan Cooke (2002); Mahd, Norita dan Abdullah (2005) menyatakan bahwa untuk mengurangi asimetri informasi, pemegang saham pengendali akan meningkatkan pengungkapan informasi untuk menyelaraskan kepentingan antar pemegang saham mayoritas dengan pemegang saham minoritas. Kepemilikan institusional dapat melakukan pengawasan lebih baik disebabkan dari segi skala ekonomik, pihak institusi memilki keuntungan lebih untuk memperoleh informasi dan menganalisis segala hal yang berkaitan dengan kebijakan manajer. Selain itu pihak institusi lebih mementingkan adanya stabilitas pendapatan atau keuntungan jangka panjang, sehingga aset penting perusahaan akan mendapatkan pengawasan yang lebih baik (Panani, 2009). Hal ini mengindikasikan semakin besar kepemilikan institusional suatu perusahaan akan semakin tinggi pengungkapan corporate social responsibility.

\section{Pengaruh Pengungkapan $C S R$ terhadap Nilai Perusahaan}

Penelitian pengaruh pengungkapan $C S R$ terhadap kinerja ekonomi menemukan hasil berbeda-beda. Preston dan Douglas (1997) melakukan penelitian terhadap 67 perusahaan pada periode 1982-1992. Penelitian tersebut menguji pengaruh kinerja sosial terhadap kinerja keuangan (ROA). Mereka membuat beberapa kenario: adanya hubungan kontemporer (tahun yang sama), hubungan lead (kinerja keuangan mendahului kinerja sosial) dan hubungan lag (kinerja sosial mendahului kinerja keuangan). Hasil penelitian menunjukkan bahwa dengan model lead ditemukan hasil lebih baik dibandingkan dengan model kontemporer ataupun lag.

Fenomena mengenai lead dan lag ini juga didukung olehWaddock dan Graves (1997) dalam penelitian mengenai pengaruh kinerja sosial terhadap kinerja keuangan. Mereka menerapkan pola leadlag sebagaimana Presto dan menggunakan ROA. Berbeda dengan pendahulunya, hasil penelitian membuktikan bahwa baik dalam posisi lead maupun lag, keduanya berpengaruh signifikan. Griffin dan Mahon (1997) menguji pengaruh kinerja sosial terhadap kinerja kinerja keuangan perusahaan pada industri kimia dengan menggunakan trianggulasi data. Ada empat jenis sumber data yang digunakan, yaitu (a) ukuran murni persepsi, yaitu survei reputasi dari majalah Fortune, (b) ukuran campuran antara ukuran persepsi dengan berbagai dimensi dari CSP, yaitu indeks KLD (Kinder, Lydenberg dan Domini), (c) laporan mandiri (dilaporkan oleh responden atau subyek penelitian) murni bersifat numerik, yaitu TRI (Toxic Release inventory) dan (d) kegiatan corporate 
filanthrofi. Dua ukuran (a) dan (b) diatas menggunakan persepsi terhadap kinerja perusahaan berasal dari berbagai kelompok audiens eksternal dan dua ukuran lainnya adalah ukuran kuatitatif diukur dari tindakan yang dilakukan perusahaan. Kinerja keuangan diproksi dengan logaritma dari total aset, return on assets, return on equity, usia aset dan returnon sales selama 5 tahun. Hasil penelitian menunjukkan bahwa penggunaan ukuran secara apriori dapat mempengaruhi hubungan antara kinerja sosial perusahaan dengan kinerja keuangan perusahaan.

Pendapat berbeda dikemukakan oleh D'Arcimoles dan Trebucq (2002)yang meneliti hubungan antara kinerja sosial dengan kinerja keuangan pada perusahaanperusahaan Perancis. Dalam menjelaskan hubungan tersebut, mereka menggunakan teori kelonggaran sumber daya (slack resources theory) dan teori manajemen yang baik (Waddock dan Graves 1997). Hasil penelitian menunjukkan bahwa kinerja sosial dengan kinerja ekonomi perusahaan. Hasil penelitian mengindikasikan bahwa: (1) dalam banyak penelitian Corporate Social Performance memiliki pengaruh positip dengan Corporate Financial Performance, (2) pengaruh $C S P$ dan $C F P$ cenderung bersifat dua arah dan simultan, dan (3) reputasi tampaknya merupakan mediator yang penting bagi pengaruh antara CSP (Corporate Social Performance) dengan CFP (Corporate Financial Performance). Dengan demikian dapat disimpulkan bahwa corporate filanthropi dalam bentuk CSR dapat memberikan keuntungan bagi perusahaan.

Pendapat serupa dikemukakan oleh Tsoutsoura (2004) yang meneliti hubungan antara kinerja sosial perusahaan dengan kinerja keuangan (diproksi dengan $R O A, R O E$, dan ROS). Sampel adalah perusahaanperusahaan Amerika Serikat. Hasil penelitian menemukan bahwa kinerja sosial perusahaan memiliki pengaruh posistip terhadap kinerja keuangan. Sayekti dan Wondobio (2007) meneliti pengaruh pengungkapan CSR terhadap earning response coefficient. Hasil penelitiannya menunjukkan bahwa pengungkapan $C S R$ berpengaruh negatif terhadap earning response coefficient. Hasil ini mengindikasikan bahwa investor kurang merespon pengungkapan CSR yang diungkapkan dalam laporan tahunan perusahaan. Fiori, et al. (2007) meneliti reaksi investor terhadap pengungkapan CSR. Hasil empirisnya menunjukkan bahwa pengungkapan CSR tidak berpengaruh signifikan terhadap stock price.
Untuk memudahkan pemahaman penelitian ini, maka kerangka konseptual penelitian ini dapat dilihat pada gambar 1 berikut ini:

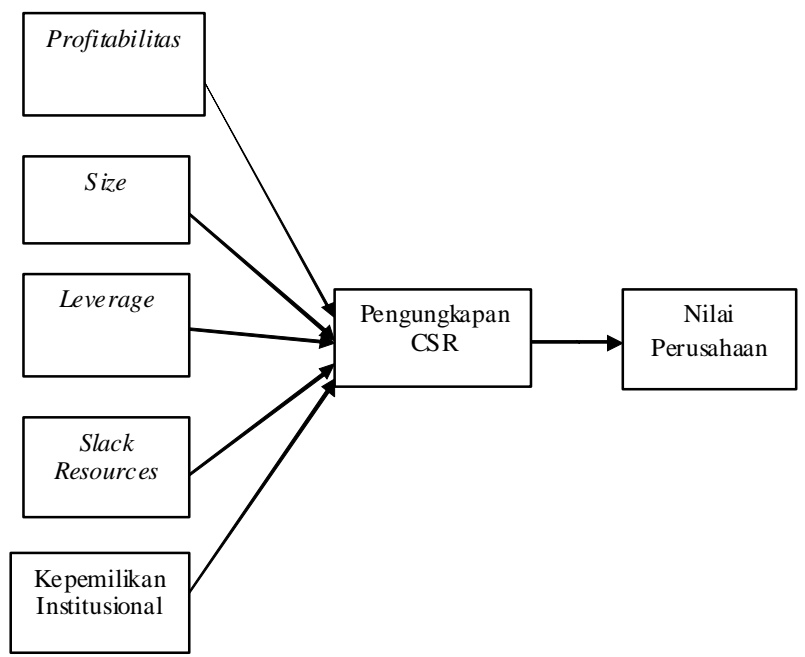

Gambar 1. Kerangka Konseptual Penelitian

Berdasarkan gambar di atas dapat di susun hipotesis dalam penelitian ini yaitu: (1) Profitabilitas, Size, Leverage, Slack Resources, dan Kepemilikan Institusional mempunyai pengaruh yang signifikan terhadap pengungkapan CSR perusahaan, (2) Pengungkapan CSR berpengaruh signifikan terhadap Nilai Perusahaan.

\section{METODE}

Populasi dalam penelitian ini adalah seluruh perusahaan manufaktur yang terdaftar di Bursa Efek Indonesia (BEI). Penentuan sampel dilakukan dengan menggunakan metode purposive samplingdengan kriteria pemilihan sampel yang digunakan adalah perusahaan manufaktur yang terdaftar di BEI sejak tahun 2010 atau sebelumnya, memiliki data yang laporan keuangan yang lengkap tahun 2010-2012, dan melakukan pengungkapan CSR selama 3 tahun berturutturut mulai tahun 2010-2012.

Dari kriteria yang telah ditentukan di atas, maka sampel dalam penelitian ini adalah PT Fajar Surya Wisesa Tbk, PT Indocement Tunggal Prakarsa Tbk, PT Holcim Indonesia Tbk, PT Semen Indonesia (Persero) Tbk, PT Asahimas Flat Glass Tbk, PT Astra Internasional Tbk, PT Astra Otopart Tbk, PT Darya-Varia Laboratoria Tbk, PT Gajah Tunggal Tbk, PT Kalbe Farma Tbk, PT Multi Bintang Indonesia Tbk, PT Unilever Indonesia Tbk, PT Gudang Garam Tbk, PT HM Sampoerna Tbkdan PT United Tractor Tbk. 


\section{Definisi Operasional Variabel}

Variabel yang digunakan dalam penelitian initerdiri atas variabel-variabel yang berkaitan dengan faktorfaktor yang yang mempengaruhi pengungkapan $C S R$, pengungkapan $C S R$ dan nilai perusahaan. Variabelvariabel yang berhubungan dengan determinan pengungkapan CSR terdiri atas profitabilitas, leverage, kepemilikan institusional, size (ukuran perusahaan), slack resources dijelaskan sebagai berikut:

\section{Profitabilitas}

Profitabilitas diartikan sebagai kemampuan perusahaan untuk menghasilkan laba atau profit dalam upaya meningkatkan nilai usaha. Dalam penelitian ini, indikator yang digunakan untuk mengukur tingkat ukuran perusahaan ini adalah Return on Asset (ROA). Return on asset (ROA) merupakan ukuran efektifitas usaha di dalam menghasilkan keuntungan dengan memanfaatkan aktiva yang dimilikinya.

\section{Size (Ukuran Perusahaan)}

Ukuran perusahaan merupakan cerminan besar kecilnya perusahaan yang tampak dalam nilai total aktiva perusahaan pada neraca akhir tahun. Ukuran perusahaan dalam penelitian ini diukur dengan logaritma naturan $(\mathrm{Ln})$ dari total aktiva. Pengukuran ini sesuai dengan pengukuran yang digunakan oleh Friend dan Lang (1988), Griffin dan mahon (1997), Wald (1999), Purnomosidhi (2005), Baroko, et al. (2006) serta Brammer dan Pavelin (2006).

\section{Leverage}

Leverege menunjukkan adanya bagian sumber pendanaan untuk operasional maupun investasi yang berasal dari luar perusahaan. Leverage perusahaan diukur dengan menggunakan proksi total utang dibagi ekuitas (DER). Rasio utang terhadap ekuitas dipilih sebagai bagian dari ukuran dari kekuasaan kreditur sebagai stakeholder karena rasioini menangkap peran penting dari kreditur sebagai stakeholder dalam perbandingannya dengan para investor ekuitas. Pengukuran ini sesuai dengan pengukuran yang digunakan dalam penelitian Belkaoui dan Karpik (1989), Robert (1992), dan Purnomosidhi (2005).

\section{Slack Resources}

Slack resources merupakan kelebihan sumber daya dari kinerja keuangan perusahaan untuk digunakan dalam pengambilan keputusan strategis yang proaktif dan inovatif. Pengukuran slack resources dalam penelitian ini sebagaimana dilakukan oleh Seifert, et al. (2004) adalah relative cash flow. Pengukuran relative cash flow dalam penelitian ini adalah cah flow dibagi dengan sales.

\section{Kepemilikan Instisional}

Kepemilikan saham institusi merupakan kepemilikan saham terbesar oleh investor institusi yang diukur dengan jumlah saham yang dimiliki oleh investor institusi dibagi total saham beredar saham. Pengukuran ini konsisten denagan penelitian Moh'd, et al. (1998) dan Sudarma (2004).

\section{Pengungkapan Corporate Social Responsibility}

Pengungkapan tanggung jawab sosial adalah inforamsi mengenai tanggung jawab sebuah organisasi terhadap dampak dari keputusan dan kegiatannya pada masyarakat dan ingkungan. Aktivitas perusahaan diwujudkan dalam bentuk perilaku transparan dan etis sejalan dengan pembangunan berkelanjutan dan kesejahteraan masyarakat. Pengungkapan CSR dalam penelitian ini diukur dengan jumlah berapa banyak $C S R$ yang telah dilakukan dan dilaporkan dalam annual report perusahaan dalam satu periode.

\section{Nilai Perusahaan}

Nilai perusahaan dalam penelitian ini menggunakan pengukuran pasar (market measure) yaitu harga saham.Harga saham diukur berdasarkan persepsi nilai perusahaan berdasarkan nilai pasar atau persepsi investor.

Share Price $=$ share price in the market

\section{Analisis Data}

Berdasarkan hubungan variabel yang digunakan dalam penelitian dan rumusan masalah, maka dalam penelitian ini untuk menganalisis datanya digunakan analisis linear regresi berganda dan uji asumsi klasik untuk menguji hipotesis yang pertama yaitu untuk melihat pengaruh profitabilitas, leverage, kepemilikan institusi, size, dan slack resources terhadap pengungkapan CSR perusahaan dengan menggunakan persamaan:

$$
\begin{aligned}
& \text { CSR }=\mathrm{b}_{0}+\mathrm{b}_{1} \text { Profit }+\mathrm{b}_{2} \text { Size }+\mathrm{b}_{3} \text { Lev }+\mathrm{b}_{4} \mathrm{SR}+\mathrm{b}_{5} \mathrm{KI} \\
& \begin{array}{ll}
\text { Di mana: } & \\
\text { CSR } & =\text { Corporate Social Responsibility } \\
\text { Profit } & =\text { Profitabilitas } \\
\text { Lev } & =\text { Leverage }
\end{array}
\end{aligned}
$$


KI

Size

$=$ Kepemilikan Institusional

SR

$\mathrm{b}_{0}$

= Ukuran Perusahaan

= Slack Resources

$\mathrm{b}_{1}, \mathrm{~b}_{2}, \mathrm{~b}_{3}, \mathrm{~b}_{4}, \mathrm{~b}_{5}=$ Koefisien Regresi

Sedangkan untuk menguji hipotesis yang kedua yaitu melihat pengaruh pengungkapan CSR terhadap nilai perusahaan, maka digunakan analisis regresi linear sederhana dengan persamaam sebagai berikut: $\mathrm{NP}=\mathrm{a}+\mathrm{b}$ CSR

Di mana:

$\mathrm{CSR}=$ Corporate Social Responsibility

$\mathrm{NP}=$ Nilai Perusahaan

Adapun Analisis data dalam penelitian menggunakan SPSS versi 17 dengan kriteria keputusan sebagai berkut: (1) Jika nilai sig ( $p$-value) lebih besar dari $\alpha=5 \%$, maka variabel independent tidak mempunyai pengaruh yang signifikan terhadap variabel dependent. (2) Jika nilai sig ( $p$-value) lebih kecil dari $\alpha=5 \%$, maka variabel independent mempunyai pengaruh yang signifikan terhadap variabel dependent.

\section{HASIL DAN PEMBAHASAN}

\section{Analisis Data Penelitian}

Hasil analisis data dengan menggunakan bantuan software SPSS versi 17 untuk persamaan regresi yang pertama di hasilkan persamaan regresi sebagai berikut: CSR $=24,430+0,156$ Profit $+0,119$ Size $-0,001463$ $\mathrm{Lev}+0,232 \mathrm{SR}+0,001 \mathrm{KI}$

Kemudian untuk melihat signifikansi variabel dependent terhadap CSR, maka berdasarkan output SPSS dapat disajikan seperti pada tabel 1.

Tabel 1. Nilai Signifikansi Faktor-Faktor yang Mempengaruhi CSR

\begin{tabular}{llrr}
\hline No & Variabel Dependent & $\begin{array}{c}\text { Koefisien } \\
\text { Regresi (b) }\end{array}$ & $\begin{array}{c}\text { Sig } \\
\text { (p-value) }\end{array}$ \\
\hline 1 & Profitabilitas & .156 & .008 \\
2 & Size & .119 & .019 \\
3 & Leverage & $-1.463 \mathrm{E}-02$ & .306 \\
4 & Slack Resources & .232 & .000 \\
5 & Kepemilikan Institusional & .001 & .863 \\
\hline
\end{tabular}

Berdasarkan tabel 1 maka dapat diketahui nilai $\operatorname{sig}(p$-value) variabel profitabilitas sebesar 0,008 , size (ukuran perusahaan) sebesar 0,19 dan slack resources sebesar 0,000. Nilai sig ( $p$-value) dari ketiga variabel tersebut lebih kecil dari $\alpha=0,05$, ini berarti bahwa variabel profitabilitas, size, dan slack resources mempunyai pengaruh yang signifikan terhadap CSR . Sedangkan untuk variabel leverage dan kepemilikan institusional tidak mempunyai pengaruh yang signifikan terhadap CSR, ini dikarnakan nilai sig ( $p$-value) leverage sebesar 0,306 dan kepemilikan institusional sebesar 0,863 lebih besar dari $\alpha=0,05$.

Sedangkan hasil analisis untuk persamaan regresi yang kedua dengan bantuan softwareSPSS versi 17, dihasilkan persamaan regresi sebagai berikut:

$\mathrm{NP}=14027,918+449,163 \mathrm{CSR}$

Adapun nilai sig ( $\mathrm{p}$-value) variabel CSR terhadap Nilai Perusahaan dapat dilihat pada tabel 2.

Berdasarkan tabel 2 dapat diketahui nilai sig ( $p$ value) CSR sebesar 0,047 dan lebih kecil dari $\alpha=$ 0,05 , ini berarti bahwa variabel CSR mempunyai pengaruh yang signifikan terhadap variabel nilai perusahaan.

\section{Pembahasan}

Berdasarkan analisis data di atas maka pembahasan analisis Faktor-Faktor yang mempengaruhi CSR dapat dijelaskan sebagai berikut:

\section{Pengaruh Profitabilitas terhadap CSR}

Berdasarkan analisis data di atas dapat diketahui bahwa profitabilitas yang di proxi dengan ROA mempunyai pengaruh yang signifikan terhadap CSR. Hasil penelitian ini sejalan dengan hasil penelitian yang dilakukan oleh Heinze (1976) yang menyatakan bahwa semakin tinggi tingkat profitabilitas perusahaan maka semakin besar pengungkapan informasi sosial yang dilakukan oleh perusahan. Hal ini menunjukkan bahwa profitabilitas merupakan faktor yang memberikan kebebasan dan fleksibilitas kepada manajemen untuk

Tabel 2. Output Persamaan Regresi Pengaruh CSR terhadap Nilai Perusahaan

\begin{tabular}{|c|c|c|c|c|c|c|}
\hline \multicolumn{7}{|c|}{ Coefficients ${ }^{a}$} \\
\hline & \multirow[t]{2}{*}{ Model } & \multicolumn{2}{|c|}{ Unstandardized Coefficients } & \multirow{2}{*}{$\begin{array}{c}\begin{array}{c}\text { Standardized } \\
\text { Coefficients }\end{array} \\
\text { Beta }\end{array}$} & \multirow[t]{2}{*}{$\mathbf{t}$} & \multirow[t]{2}{*}{ Sig. } \\
\hline & & B & Std. Error & & & \\
\hline \multirow[t]{2}{*}{1} & (Constant) & 14207.918 & 6486.456 & & 2.190 & .034 \\
\hline & CSR & 449.163 & 208.148 & .131 & 2.157 & .047 \\
\hline
\end{tabular}

a. Dependent Variable: NP 
mengungkapkan pertanggungjawaban sosial kepada pemegang saham.

Pengungkapan CSR merupakan cerminan suatu pendekatan manajemen dalam menghadapi lingkungan yang dinamis dan multidimensional serta kemampuan untuk mempertemukan tekanan sosial dengan reaksi kebutuhan masyarakat. Dengan demikian, ketrampilan manajemen perlu dipertimbangkan untuk survive dalam lingkungan perusahaan masa kini (Cowen, et al ., 1987 dalam Heckston dan Milne, 1996).

Hubungan antara pengungkapan $C S R$ dan profitabilitas perusahaan telah dipostulasikan untuk merefleksikan pandangan bahwa kepekaan sosial membutuhkan gaya managerial yang sama sebagaimana yang diperlukan untuk dapat membuat perusahaan menguntungkan (profitable) Bowman dan Haire (1976) dalam Heckston dan Milne (1996). Tetapi hasil penelitian ini bertentangan dengan penelitiannya Belkaoui dan Karpik (1989) melaporkan bahwa profitabilitas tidak berpengaruh terhadap pengungkapan tanggung jawab sosial perusahaan.

\section{Pengaruh Size (Ukuran Peusahaan) terhadap CSR}

Berdasarkan analisis data di atas dapat diketahui bahwa ukuran perusahaan yang di proxi dengan total aktiva mempunyai pengaruh yang signifikan terhadap CSR. Hasil penelitian ini sejalan dengan hasil penelitian yang dilakukan oleh Belkaoui, dan Karpik 1989; Purnomosidhi, 2005; Brammer dan Pavelin, 2006; Reverte, 20009; dan Rofelawati, 2010 yang menyatakan Ukuran perusahaan dalam berbagai penelitian terbukti merupakan faktor signifikan dalam menjelaskan perbedaan tingkat pengungkapan informasi $C S R$.

Hal ini disebabkan antara lain adanya kebutuhan untuk memperoleh dana dengan biaya rendah, desakan dari para stakeholder dan analisis investasi untuk memperoleh informasi yang lebih banyak, pemantauan yang dilakukan pemerintah semakin ketat, struktur bisnis yang semakin rumit, dan tuntutan yang semakin besar untuk menyediakan informasi bagi berbagai kelompok pemakai (Purnomosidhi, 2005).

\section{Pengaruh Leverage terhadap CSR}

Berdasarkan analisis data di atas dapat diketahui bahwa leverage yang di proxi dengan proksi dengan total utang dibagi ekuitas (DER) mempunyai pengaruh yang tidak signifikan terhadap CSR. Hasil penelitian ini tidak mendukung dengan hasil penelitian yang dilakukan oleh Cornell dan Shapiro (1987) dan Barton,
Hill dan Sundaram (1989) yang menemukan bahwa keputusan struktur modal adalah bagian dari struktur stakeholder perusahaan secara keseluruhan dan kreditur adalah stakeholder penting yang memiliki pengaruh harus dikelola oleh perusahaan. Dengan demikian, dapat disimpulkan bahwa semakin bergantung sebuah perusahaan pada pendanaan utang untuk mendanai proyeknya, semakin besar tingkat respon yang diberikan manajemen terhadap pengharapan kreditur atas peran perusahaan dalam melaksanakan kegiatan tanggung jawab sosial.

\section{Pengaruh Slack Resources terhadap CSR}

Berdasarkan analisis data di atas dapat diketahui bahwa leverage yang diproxi dengan proksi dengan cah flow dibagi dengan sales mempunyai pengaruh yang signifikan terhadap CSR. Hasil penelitian ini sejalan dengan pandangan Cyert dan March (1963) yang menyatakan ketersediaan sumber daya berlebih melampaui tingkat sumber daya minimal yang diperlukan untuk mempertahankan keutuhan dari organisasi.

Slack resources yang dimiliki perusahaan dapat digunakan untuk memenuhi kewajiban kepada pemegang saham dan akan lebih kecil kemungkinannya untuk mendapatkan tekanan dari stakeholder keuangan lain seperti kreditur. Dengan demikian, implementasi CSR diharapkan dapat menjadi peredam keinginan stakeholder perusahaan.

\section{Pengaruh Kepemilikan Institusional terhadap CSR}

Berdasarkan analisis data di atas dapat diketahui bahwa kepemilikan institusional mempunyai pengaruh yang tidak signifikan terhadap CSR. Hasil penelitian ini tidak mendukung dengan hasil penelitian yang dilakukan oleh Panani (2009) mengindikasikan semakin besar kepemilikan institusional suatu perusahaan akan semakin tinggi pengungkapan corporate social responsibility.

\section{Dampak CSR terhadap Nilai Perusahaan}

Berdasarkan analisis data di atas dapat diketahui bahwa $C S R$ mempunyai pengaruh yang signifikan terhadap nilai perusahaan yang di proxi dengan harga saham. Hasil penelitian ini sejalan dengan hasil penelitian yang dilakukan oleh Preston dan Douglas (1997) dan Tsoutsoura (2004). menemukan bahwa kinerja sosial perusahaan memiliki pengaruh posistip terhadap kinerja keuangan. Di samping itu juga Waddock dan Graves (1997) dalam hasil penelitiannya menunjukkan 
bahwa kinerja sosial dengan kinerja ekonomi perusahaan. Hasil penelitian mengindikasikan bahwa: (1) dalam banyak penelitian Corporate Social Performance memiliki pengaruh positip dengan Corporate Financial Performance, (2) pengaruh CSP dan CFP cenderung bersifat dua arah dan simultan, dan (3) reputasi tampaknya merupakan mediator yang penting bagi pengaruh antara CSP (Corporate Social Performance) dengan CFP (Corporate Financial Performance). Dengan demikian dapat disimpulkan bahwa corporate filanthropi dalam bentuk CSR dapat memberikan keuntungan bagi perusahaan yang akan tercermin dalam harga saham perusahaan.

Hasil penelitian ini bertentangan dengan hasil penelitian yang dilakukan oleh Fiori, et al. (2007) meneliti reaksi investor terhadap pengungkapan CSR. Hasil empirisnya menunjukkan bahwa pengungkapan CSR tidak berpengaruh signifikan terhadap stock price.

\section{KESIMPULAN DAN SARAN}

\section{Kesimpulan}

Berdasarkan hasil analisis data dan pembahasan hasil penelitian, maka dapat disimpulkan pertama, faktor-faktor yang mempengaruhi secara signifikan terhadap pengungkapan $C S R$ pada perusahaan manufaktur yang terdaftar di BEI adalah profitabilitas, Size (ukuran perusahaan), dan slack resources. Profitabilitas mempunyai mempunyai pengaruh yang signifikan positif terhadap CSR menunjukkan bahwa semakin tinggi tingkat profitabilitas perusahaan maka semakin besar pengungkapan informasi sosial yang dilakukan oleh perusahan. Hal ini mengindikasikan bahwa profitabilitas merupakan faktor yang memberikan kebebasan dan fleksibilitas kepada manajemen untuk mengungkapkan pertanggungjawaban sosial kepada pemegang saham.

Sedangkan Size (ukuran perusahaan) dalam hasil penelitian ini dan dalam berbagai penelitian terbukti merupakan faktor signifikan dalam menjelaskan tingkat pengungkapan CSR. Begitu juga slack resources mempunyai mempunyai pengaruh yang signifikan terhadap CSR. Hal ini menunjukkan bahwa implementasi CSR diharapkan dapat menjadi peredam tekanan dan keinginan stakeholder perusahaan seperti kreditur dalam pengguanaan slack resources yang dimiliki perusahaan. Adapun untuk faktor leverage dan kepemilikan institusional dari hasil penelitian ini tidak mempunyai pengaruh yang signifikan terhadap $C S R$. Kedua, dampak CSR terhadap nilai perusahaan dari hasil penelitian ini menunjukan bahwa CSR mempunyai pengaruh yang sinifikan terhadap nilai perusahaan. Hal ini menunjukkan bahwa CSR dapat memberikan keuntungan bagi perusahaan yang akan tercermin dalam harga saham perusahaan.

\section{Saran}

Berdasarkan beberapa kesimpulan yang telah diungkapkan, maka diberikan saran untuk perusahaan, investor, dan peneliti selanjutnya yaitu: Pertama, hendaknya perusahaan saat ini mulai memperhatikan tentang $C S R$, karena perusahaan tidak dapat dipisahkan dengan masyarakat sebagai lingkungan eksternalnya; Kedua, investor pada saat akan menanamkan dananya pada bursa efek harus mulai selektif dengan memperhatikan perusahaan yang melakukan CSR. Hal ini dikarenakan pengungkapan CSR akan berdampak pada nilai perusaan yang tercermin dari stock price perusahaan; Ketiga, hendaknya peneliti berikutnya menambahkan variabel faktor-faktor yang mempengarui $C S R$ yang belum dimasukkan dalam penelitian ini untuk mendapatkan hasil penelitian yang komprehenif berkaitan dengan CSR dan dampaknya terhadap nilai perusahaan.

\section{DAFTAR RUJUKAN}

Ahmad, H., dan Mohammad. 2003. Determinants of Environmental Reporting in Malaysia, International Journal of Business Studies, Vol.11 (1):69-90.

Barako, D.G., Hancock, P., dan Izan, H.Y. 2006. Factors Influencing Voluntary Corporate Disclosure by Kenyan Companies, Journal Compilation, Vol 14 (2):107-125.

Barton, H., dan Sundaram. 1989. "How firm Characteristics Affect Capital Structure: an Interbational Comparison. Journal of Financial Research 22(2)161-187.

Belkaoui, A., and Karpik, P.G. 1989. "Determinants of the Corporate Decision to Disclose Social Information". Accounting, Auditing and Accountability Jounal. vol. 1, No.1.

Brammer, S., dan S. Pavelin. 2006. " Voluntary Environmental Disclosure by Large UK Companies, Journal of Business Finance and Accounting, Vol 33 (7-8):11681188.

Cowen, S.S., Ferreri, L.B., dan Parker, L.D. 1987. The Impact of Corporate Characteristics on Sosial Responsibility Disclosure: a Typology Frequency based Analysis", Accounting, Organization and Society Vol 12. No.2.p.11-22.

Curcio dan Wolf. 1996. The Impact of Corporate Social Responsibility in Shareholder Wealth Academy of Management Journal. 
Darwin. 2007. "A Study of Environmental disclosure practices of Australian Corporations", Accounting and Business Research, Vol.26 No.3, pp. 187-199.

D'Arcimoles dan Trebucq. 2002. "Corporate Social Responsibility and Firm Financial Performance", Accounting Management Journal, 31:4, pp 854-872.

Fiori, et al. 2007. The Value Relevance of Environmental Performance", European Accounting Review, Vol 14 (1).

Friedman. 1962." Stockholders and Stockholders: A new Perspective on Corporate On Corporate Governance". Californian Management Review, Vol. 25, no. 2, hal. 88-106.

Freeman dan Elkington. 1998. "Business Ethics, Corporate Good Citizenship and the Corporate Social Policy Process: A View from The United States". Journal of Business Ethics. Vol. 8. pp. 583-595.

Freeman, R.E. 1984. Strategic Management: A Stakeholder Approach, Pitman, Massachusetts.

Friend, I., dan L. Lang. 1988. An Empirical Test of The Impact of Managerial Self-Interst on Corporate Capital Structure. Journal of Finance, 43,271-281.

Griffin, J.J., dan John, M.M. 1997. ’The Corporate Social Performance and Corporate Financial Performance Debate", Business and Society, 36:1, pp 5-31.

Guenster, N., Jeroen, D., Rob, B., dan Kees, K. 2005. The Economic Value of Corporate Eco-Efficiency. Academy of Management Conference Paper. Netherlands.

Hackson and J. Milne 1996. ”Some ,Determinants of Social and Environmental Disclosures in New Zealand Companies", Accounting, Auditing, Accountability Journal. Vol. 9. no. 1. Pp. 77-107.

Haniffa dan Cooke.2005. "The Impact of Culture and Governance on Corporate Social" Reporting. Journal of Accounting and Public Policy. Elsevier. 391-430.

Heinze. 1976. "The Evolution of The Corporate Social Performance Model". Academy of Management Review. Vol.10.pp.758-769

Hubert dan Langge. 2002. ”The Impact of Environmental Management on Firm Performance", Management Science, 42:8, pp 1199-1214.
Husnan, S. 2006. Manajemen Keuangan. Yogyakarta: UPP STIM YKPN.

Menon, A., dan Menon, A. 1997. "Enviropreneurial Marketing Strategy: The Emergence to Corporate Environmentalism as Market Strategy. Journal of Marketing. 61:51-67.

Preston, L., dan Daouglas O Bannon. 1997. "The Corporate Social-Financial Performance', Business and Society, 36:4, pp 419-429.

Purnomosidhi, B. 2005. Analisis Empiris terhadap Determinan Praktek Pengungkapan Modal Intelectual pada Perusahaan Publik di BEJ. Malang: Disertasi Universitas Brawijaya Malang.

Reverta. 2009. "Factors Influencing Corporate Social and Ethical Reporting: Moving on From Extant Theories", Accounting, Auditing and Accountability Journal, 15:2, pp 223-250.

Sarumpaet, S. 2005. 'The Relationship between Environmental Performance and Financial Performance of Indonesian Companies", Working Paper, Jurusan Akuntansi FE Universitas Kristen Petra.

Sharfman. 1988." An Empirical Examination of The Relationship Between Corporate Social Responsibility and Profitability", Academy of Management Journal, 28:2, pp446-463.

Sudarma, M. 2004. Pengaruh Struktur Kepemilkan Saham, Factor Intern dan Faktor Ekstern terhadap Struktur Modal dan Nilai Perusahaan, Studi pada Industri yang Go Publik di BEJ. Malang: Disertasi Universitas Brawijaya.

Tsoutsoura. 2004. "Corporate Social Responsibility and Firm Financial Performance", Accounting Management Journal, 31:4, pp 854-872.

Ullman, A. 1985. Data in Search of Theory: A Critical Examination of The Relationship Among Social Performance Social Disclosure and Economic Performance, Academy of Management Review, 10, pp 540-577.

Waddock, S.A., dan Samuel, B.G. 1997. "The Corporate Social Performance and Financial Performance link", Strategic Management Journal, !8:4, pp 303-319. 